\title{
NAVIGASI BERBASIS BEHAVIOR DAN FUZZY LOGIC PADA SIMULASI ROBOT BERGERAK OTONOM
}

\author{
Rendyansyah*, Kemahyanto Exaudi, Aditya Putra Perdana Prasetyo \\ Jurusan Sistem Komputer, Fakultas Ilmu Komputer, Universitas Sriwijaya \\ *Corresponding author, e-mail : rendyansyah@ilkom.unsri.ac.id
}

\begin{abstract}
Abstrak-Mobile robot merupakan mekanisme robot yang mampu bergerak otomatis. Pergerakan robot secara otomatis memerlukan suatu sistem navigasi. Navigasi adalah metode untuk menentukan gerak robot. Pada penelitian ini navigasi robot dikembangkan menggunakan metode behavior (perilaku) dengan logika fuzzy. Perilaku robot dibagi menjadi beberapa modul, seperti berjalan, menghindari halangan, mengikuti dinding, koridor maupun kondisi $u$-shape. Pada penelitian ini dirancang simulasi mobile robot di dalam pemrograman visual. Robot dilengkapi dengan tujuh sensor jarak dan dibagi menjadi beberapa kelompok untuk menguji perilaku yang dirancang, sehingga perilaku robot menghasilkan pengaturan kecepatan dan steering. Berdasarkan percobaan yang telah dilakukan menunjukkan bahwa simulasi mobile robot dapat berjalan mulus (smooth) pada berbagai kondisi. Hal ini membuktikan bahwa implementasi pembentukan behavior dan teknik logika fuzzy pada robot bekerja dengan baik.
\end{abstract}

Kata Kunci : behavior, logika fuzzy, mobile robot

\begin{abstract}
Mobile robot is the robotic mechanism that is able to moved automatically. The movement of the robot automatically require a navigation system. Navigation is a method for determining the robot motion. In this study, using a method developed robot navigation behavior with fuzzy logic. The behavior of the robot is divided into several modules, such as walking, avoid obstacles, to follow walls, corridors and conditions of u-shape. In this research designed mobile robot simulation in a visual programming. Robot is equipped with seven distance sensor and divided into several groups to test the behavior that is designed, so that the behavior of the robot generate speed and steering control. Based on experiments that have been conducted shows that mobile robot simulation can run smooth on many conditions. This proves that the implementation of the formation of behavior and fuzzy logic techniques on the robot working well.
\end{abstract}

Keywords : behavior, fuzzy logic, mobile robot

Copyright $(2016$ JNTE. All rights reserved

\section{PENDAhUluaN}

Mobile robot dirancang untuk bergerak secara otomatis atau dikenal robot bergerak otonom, robot yang dapat bergerak bebas pada area yang tidak terstruktur dan dapat menentukan sendiri jalur pergerakannya. Robot otonom identik sebagai robot cerdas karena sistem-nya menggunakan teknik kendali cerdas (artificial intelligence) untuk mengontrol pergerakan. Kontrol gerakan robot ini dikenal istilah navigasi cerdas [1].

Navigasi merupakan suatu metode dalam menentukan aksi dari pergerakan robot di dalam lingkungan [1]. Navigasi cerdas diaplikasikan pada robot bergerak otonom agar dapat membuat keputusan sendiri. Saat ini banyak dikembangkan suatu sistem navigasi robot bergerak otonom menggunakan logika fuzzy
[2][3][4], teknik jaringan saraf [1][4], bahkan gabungan dari keduanya (neuro-fuzzy) [5]. Metode yang paling sering digunakan yaitu logika fuzzy kerena proses fuzzy bisa diimplementasikan ke dalam sistem mikro [2][6] Algoritma logika fuzzy digunakan dalam aplikasi kendali yang memerlukan waktu komputasi cepat, oleh karena itu dapat diaplikasikan ke robot dengan banyak behavior.

Sistem navigasi cerdas pada robot bergerak otonom dengan menirukan prilaku atau reaksi terhadap keadaan lingkungan yang dihadapi. Metode behavior dapat bekerja pada lingkungan yang dinamis, salah satu contoh behavior pada robot dalam mencari target [2][7]. Metode behavior terinspirasi dari sifat prilaku makhluk hidup saat berinteraksi dengan lingkungannya [8]. Behavior tersebut terjadi karena alat indra menerima informasi sehingga ada respon gerak. 
Dalam kasus robot bergerak otonom, informasi diperoleh dari sensor dan respon keluaran berupa pergerakan.

Pada penelitian ini diimplementasikan behavior sebagai penentu aksi gerak, dan fuzzy logic sebagai kendali cerdas untuk mengontrol posisi dan kecepatan robot. Kombinasi tersebut bertujuan untuk menghasilkan respon pergerakan yang halus (smooth) dalam bernavigasi pada lingkungan komplek yang tak terstruktur. Pergerakan mobile robot dan lingkungan disimulasikan ke dalam tampilan visual.

\section{TINJAUAN PUSTAKA}

\subsection{Metode Berbasis Behavior}

Metode behavior juga dikenal sebagai arsitektur subsumption merupakan prilaku yang meniru sifat alami makhluk hidup dan tergolong ke dalam algoritma high-level control [8]. Adapun ilustrasi dari arsitektur behavior ditunjukkan pada Gambar 1.

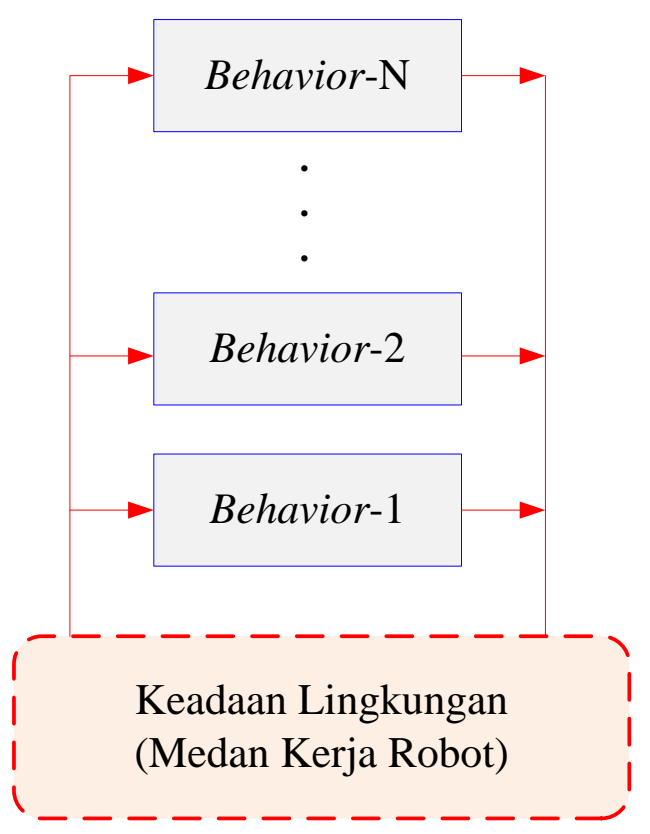

Gambar 1. Arsitektur behavior [8].

Berdasarkan arsitektur pada Gambar 1, behavior dapat diterapkan pada robot bergerak otonom dengan membentuk tingkat behavior. Adapun tingkat behavior menentukan prioritas, semakin tinggi tingkat behavior maka dapat men-skip tingkat yang lebih rendah. Tingkat behavior tersebut terjadi karena adanya stimuli atau rangsangan yang didapat dari lingkungan. Behavior pada robot dirancang berdasarkan strategi-strategi yang diinginkan dalam menemukan targetnya [9].

Berdasarkan strategi behavior ini, maka penulis mengaplikasikan teknik behavior pada robot untuk membagi tugas robot dalam bernavigasi.

\subsection{Algoritma Logika Fuzzy}

Logika fuzzy bekerja atas dasar logika dan keinginan dari seorang ahli [6][10]. Pada perancangan logika fuzzy memiliki beberapa tahapan [11][12], yaitu : (1) fuzzifikasi, (2) basis aturan dan meknisme inference, dan (3) defuzzifikasi. Gambar 2 memperlihatkan diagram blok algoritma logika fuzzy.

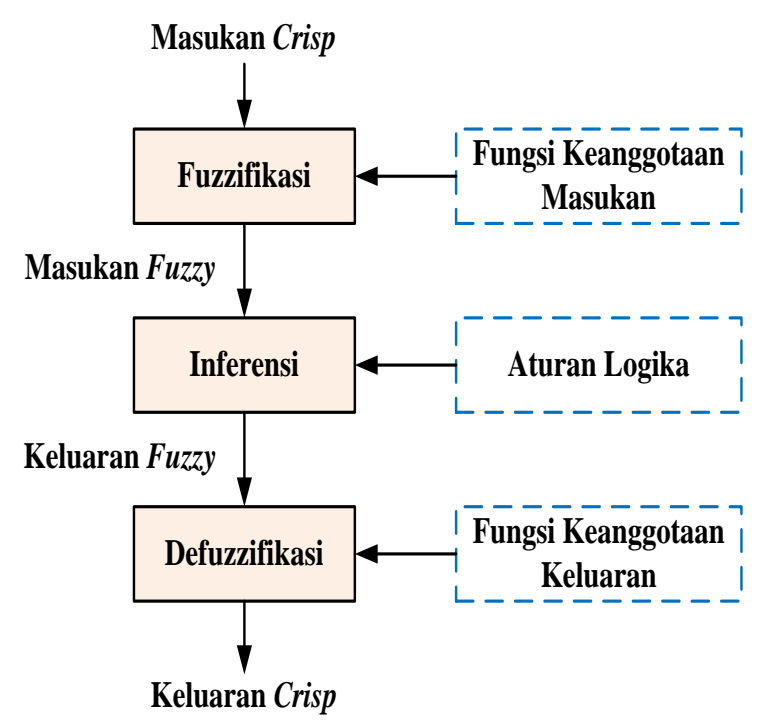

Gambar 2. Diagram blok logika fuzzy [13].

Penjelasan tahapan algoritma logika fuzzy :

1. Fuzzifikasi.

Fuzzifikasi akan mengubah nilai masukan crisp menjadi nilai fuzzy. Nilai fuzzy dipengaruhi oleh fungsi keanggotaan yang dirancang oleh pakar.

2. Basis aturan dan mekanisme inference.

Aturan (rule) berisi logika-logika dari seorang pakar dalam menentukan aksi sistem. Oleh karena itu basis aturan yang ditetapkan dengan mengintegrasikan variabel masukan dengan variabel keluaran fungsi keanggotaan. Aturan ini berupa logika "jika - maka" seperti :

if $X_{1}$ is $A_{1}$ and ... and $X_{n}$ is $A_{n}$, then $Y$ is $B$ 
Aturan-aturan tersebut dibutuhkan penalaran dalam pengambilan keputusan akhir, sehingga pada tahap ini akan menghasilkan keluaran fuzzy. Mekanisme dalam pengambilan keputusan menggunakan metode "Max-Min" seperti :

$\mu_{B}(y)=\max \left[\min \left[\mu_{A 1}(\operatorname{input}(i)), \mu_{A 2}(\operatorname{input}(j)), \ldots\right]\right]$

3. Defuzzifikasi.

Defuzzifikasi akan mengkonversi nilai keluaran fuzzy menjadi nilai keluaran crisp. Proses ini juga dirancang fungsi keanggotaan keluaran. Metode umum yang sering dipakai dalam komputasi defuzzifikasi yaitu metode centroid atau weighted average [12][14].

\section{METODOLOGI}

Sistem robotik dalam penelitian ini menggunakan simulasi di dalam program visual. Oleh karena itu, dibuatlah rancangan navigasi berbasis behavior dan logika fuzzy pada simulasi tersebut.

\subsection{Perancangan Behavior}

Di dalam simulasi, robot berbentuk bulat dengan diameter $15 \mathrm{~cm}$ dan dilengkapi tujuh sensor jarak, penggerak kecepatan dan sudut belok (steering). Gambar 3 menunjukkan bentuk robot dan peletakan sensor jarak. Simulasi robot dijalankan dalam arena pada Gambar 4. Behavior pada robot dalam menavigasi dikelompokan menjadi beberapa kelompok, yaitu: perilaku maju, mengikuti dinding kiri atau kanan, mengikuti jalur koridor, menghindar halangan dan kondisi u-shape. Adapun diagram blok behavior untuk navigasi robot ditunjukkan pada Gambar 5.

Berdasarkan Gambar 5, bahwa prioritas paling tinggi yaitu behavior dalam kondisi terlalu dekat dengan halangan (u-shape), dan yang paling rendah pada behavior bergerak maju. Adapun behavior dalam simulasi robot didefinisikan sebagai berikut :

1. Bergerak maju: robot bergerak bebas kearah depan dengan kecepatan konstan, karena tidak ada halangan atau halangan dianggap jauh.

2. Mengikuti dinding kanan: ikuti jika terdeteksi dinding kanan. Jika jarak yang dideteksi oleh sensor $\mathrm{S}_{6}$ dan $\mathrm{S}_{7}$ masing- masing kurang dari $40 \mathrm{~cm}$ dan $30 \mathrm{~cm}$ maka robot akan mengikuti dinding kanan.

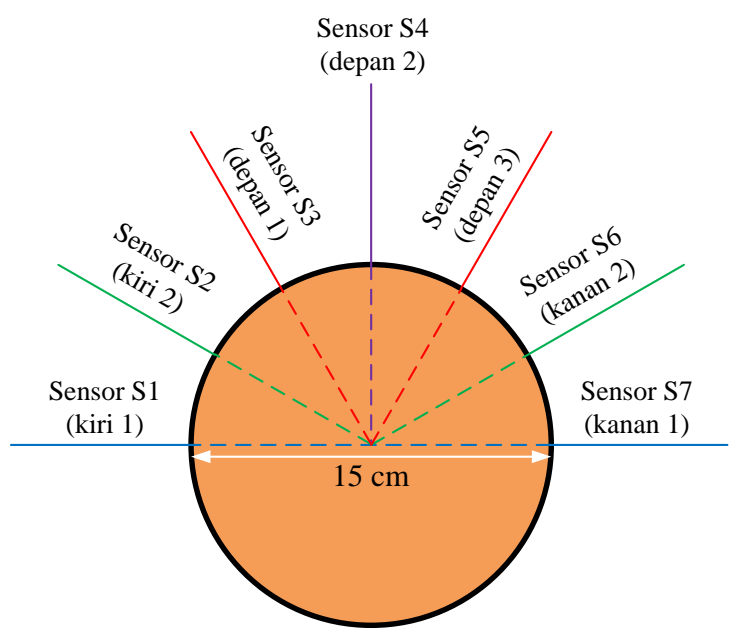

Gambar 3. Bentuk robot dan peletakan tujuh sensor jarak.

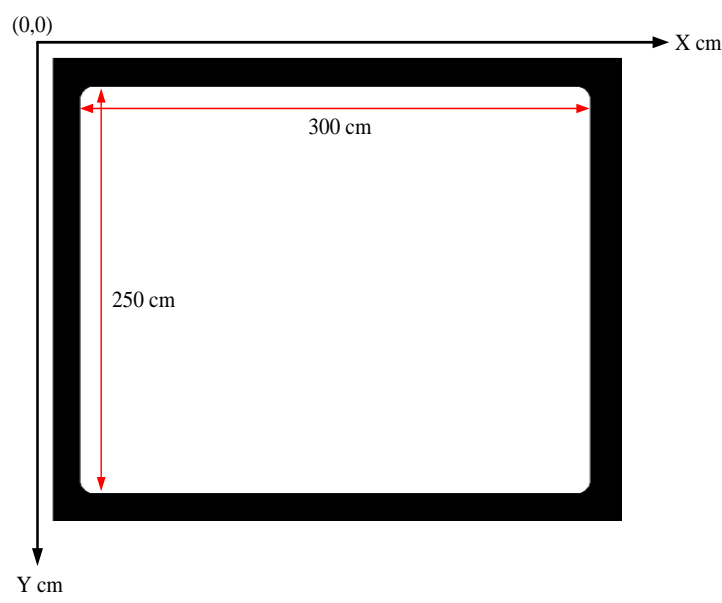

Gambar 4. Simulasi arena robot.

3. Mengikuti dinding kiri: ikuti jika terdeteksi dinding kiri. Jika jarak yang dideteksi oleh sensor $S_{1}$ dan $S_{2}$ masing-masing kurang dari $30 \mathrm{~cm}$ dan $40 \mathrm{~cm}$ maka robot akan mengikuti dinding kiri.

4. Mengikuti jalur koridor: jika sensor kanan $\left(\mathrm{S}_{6}\right)$ dan kiri $\left(\mathrm{S}_{2}\right)$ mendeteksi jarak kurang dari 40 $\mathrm{cm}$, artinya robot menganggap jalur koridor. Robot akan berjalan pada posisi tengah jalur koridor tersebut.

5. Menghindar halangan: Hindari jika ada halangan depan. Prilaku ini diaktifkan saat sensor depan $\left(\mathrm{S}_{4}\right)$ mendeteksi jarak kurang dari $60 \mathrm{~cm}$. Gerakan belok kiri atau kanan berdasarkan informasi dari sensor $\mathrm{S}_{3}$ dan $\mathrm{S}_{5}$. 


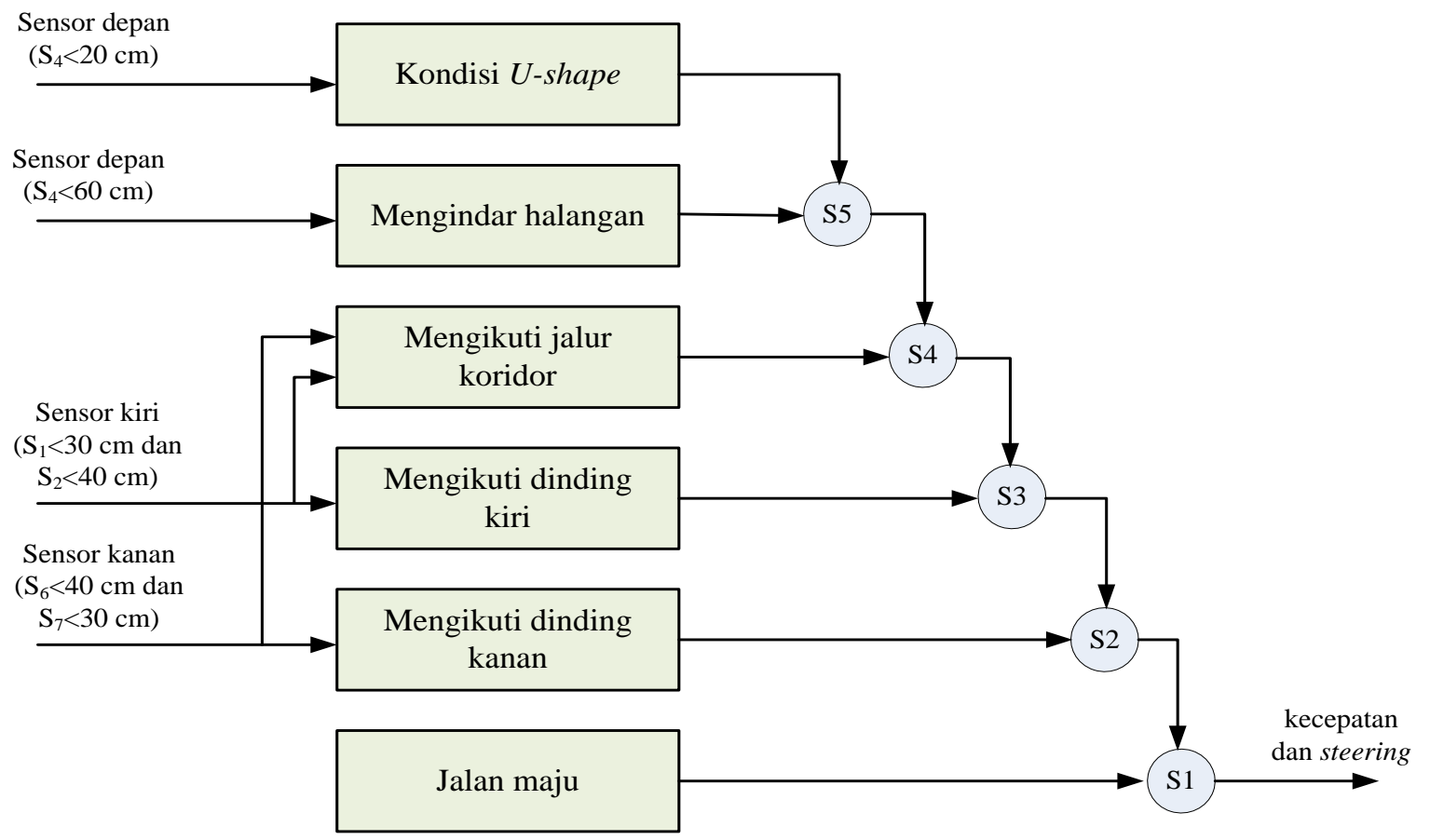

Gambar 5. Arsitektur behavior untuk navigasi pada robot dalam simulasi.

6. Kondisi U-shape: Jika hanya sensor $\mathrm{S}_{4}$ mendeteksi jarak yang terlalu dekat (kurang dari $20 \mathrm{~cm}$ ) maka robot ber-manuver kearah kiri ataupun kanan berdasarkan informasi dari sensor $S_{1}$ dan $S_{7}$. Jika sensor $S_{1}<S_{7}$ maka belok kanan, dan sebaliknya.

Pada behavior dalam navigasi robot, penulis menambahkan logika fuzzy guna menghasilkan gerak robot yang baik. Logika fuzzy diimplementasikan pada beberapa behavior diantaranya menghindar halangan, mengikuti dinding kanan atau kiri, dan mengikuti koridor.

\subsection{Perancangan Logika Fuzzy}

Logika fuzzy pada behavior robot bekerja berdasarkan informasi sensor-sensor jarak untuk mengendalikan gerak kecepatan dan steering. Adapun rancangan logika fuzzy untuk behavior robot :

\subsubsection{Behavior menghindar halangan}

Masukan crisp dari behavior ini yaitu tiga sensor jarak pada bagian depan robot (kiri depan $\left(S_{3}\right)$, depan $\left(S_{4}\right)$, kanan depan $\left(S_{5}\right)$ ). Keluaran dari logika fuzzy pada behavior ini menghasilkan crisp respon gerak kecepatan dan steering. Proses rancangan fungsi keanggotaan untuk tiga sensor jarak ini dengan melakukan tahap trial and error untuk mengetahui respon robot terhadap halangan. Pada behavior ini tiga sensor jarak tersebut dibatasi jarak maksimum $60 \mathrm{~cm}$, sehingga diperoleh masukan jarak yang dibagi menjadi tiga variabel linguistik yaitu dekat, sedang dan jauh. Jika terdeteksi jarak dalam area dekat maka robot harus ber-manuver besar kearah tempat yang tidak ada halangan. Jika jarak sedang maka robot ber-manuver sedang. Jika jaraknya jauh maka robot ber-manuver sedikit. Betuk dan ukuran robot juga mempengaruhi respon gerak, misal robot berukuran lebih besar atau kecil maka jarak maksimumnya bisa diganti. Adapun fungsi keanggotaan untuk masukan nilai jarak ditunjukkan pada Gambar 6.

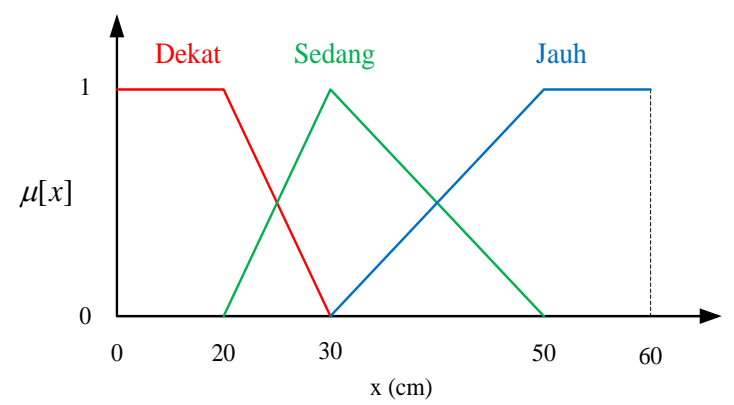

Gambar 6. Fungsi keanggotaan untuk masukan jarak pada sensor $S_{3}, S_{4}$ dan $S_{5}$. 


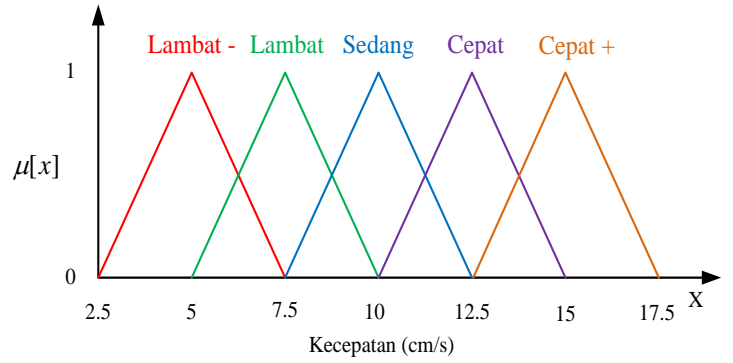

(a)

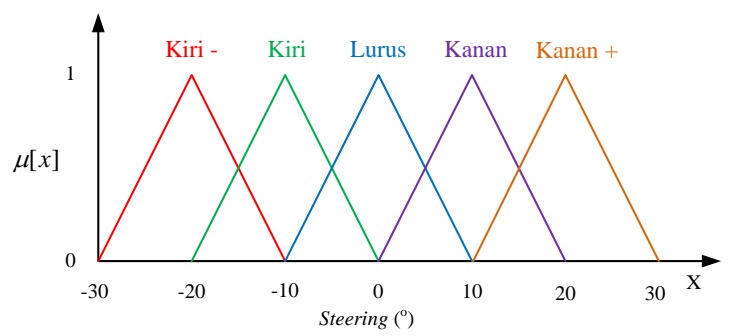

(b)

Gambar 7. Fungsi keanggotaan untuk keluaran. (a) kecepatan, (b) steering.

Keluaran respon kecepatan dan steering masing-masing terdiri lima variabel linguistik seperti pada Gambar 7. Berdasarkan Gambar 7 bahwa rentang kecepatan yang diberikan pada robot yaitu $2.5 \mathrm{~cm} / \mathrm{s}$ sampai $17.5 \mathrm{~cm} / \mathrm{s}$ dan steering $-30^{\circ}$ sampai $30^{\circ}$. Pengambilan keputusan pada fungsi keanggotaan keluaran menggunakan scaled fuzzified decision, dan digunakan juga pada behavior lain.

Tabel 1. Aturan logika untuk menghindar halangan.

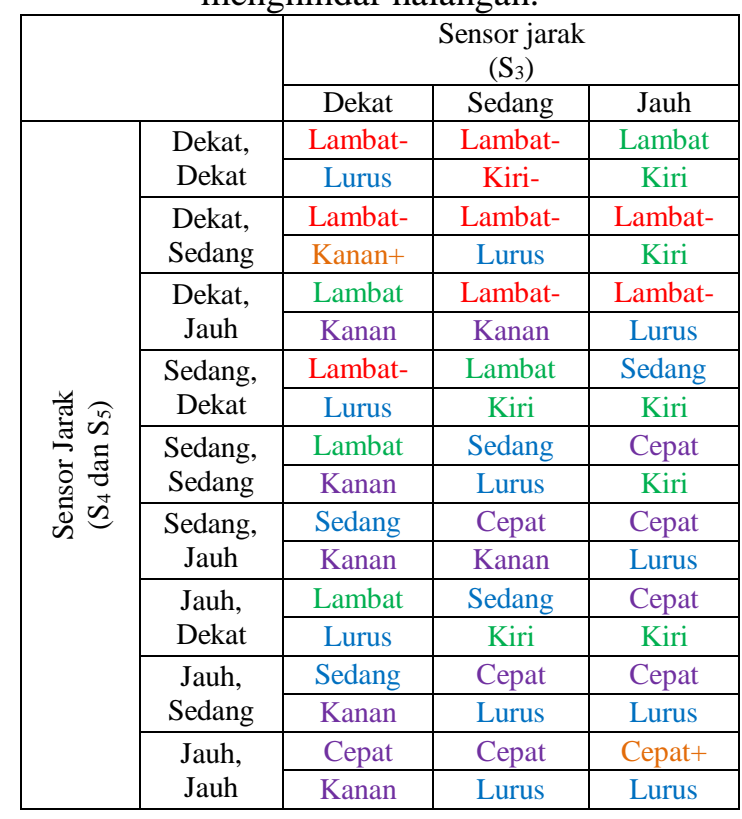

Berdasarkan kombinasi dari informasi fungsi keanggotaan masukan dan keluaran, menghasilkan 27 aturan logika untuk pergerakan robot menghindar halangan. Adapun aturan logika untuk menghindar halangan seperti ditunjukkan pada Tabel 1.

\subsubsection{Behavior mengikuti dinding kanan atau kiri}

Behavior ini diaktifkan saat sensor jarak bagian kanan robot mendeteksi dinding kanan, begitu juga untuk sensor bagian kiri. Masukan dari sensor kanan yaitu $S_{7}$ dan $S_{6}$, atau kiri yaitu $S_{1}$ dan $S_{2}$. Proses rancangan fungsi keanggotaan sensor jarak juga dilakukan tahap trial and error. Dalam kasus ini, sensor $S_{1}$ dan $S_{7}$ terdiri atas variabel dekat dan sedang dengan jarak maksimum $30 \mathrm{~cm}$, untuk sensor $S_{2}$ dan $S_{6}$ dengan variabel dekat, sedang dan jauh dengan jarak maksimum $40 \mathrm{~cm}$. Jika jarak dalam area dekat maka robot harus belok menjauhi dinding, dan jika jarak dalam area jauh maka robot harus belok mendekati dinding. Adapun fungsi keanggotaan untuk nilai jarak ditunjukkan pada Gambar 8. Behavior ini juga menghasilkan keluaran crisp untuk kecepatan dan steering. Untuk keluaran kecepatan dan steering sama seperti pada behavior menghindar halangan, sehingga grafik fungsi keanggotaannya juga digunakan sama seperti pada Gambar 7.

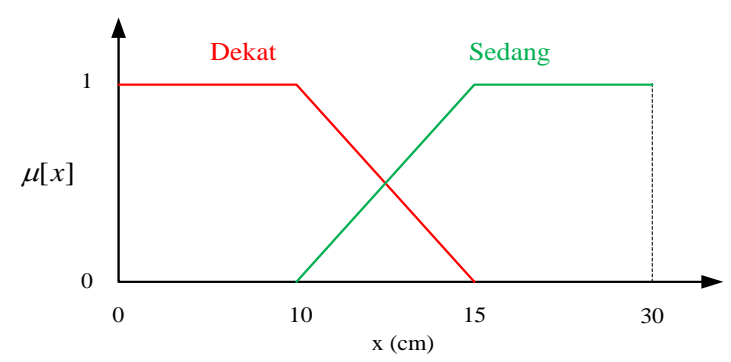

(a)

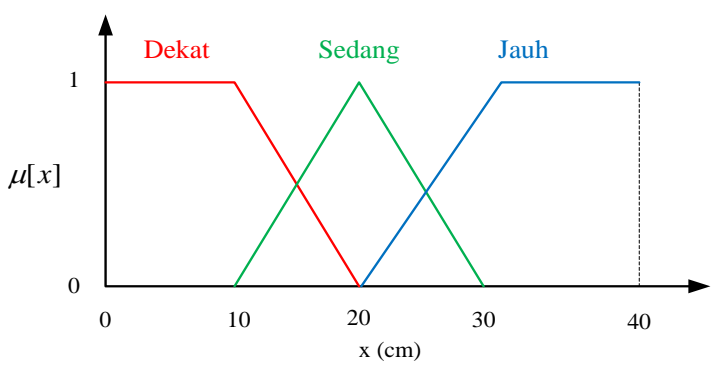

(b)

Gambar 8. Fungsi keanggotaan untuk masukan jarak, (a) sensor $S_{1}$ dan $S_{7}$, (b) sensor $S_{2}$ dan $S_{6}$. 
Kombinasi dari masukan dan keluaran pada behavior mengikuti dinding kanan atupun kiri masing-masing menghasilkan enam aturan logika. Adapun aturan logika mengikuti dinding kanan seperti pada Tabel 2, dan aturan logika mengikuti dinding kiri pada Tabel 3.

Tabel 2. Aturan logika untuk mengikuti dinding kanan.

\begin{tabular}{|c|c|c|c|}
\hline & \multicolumn{2}{|c|}{$\begin{array}{c}\text { Sensor jarak } \\
\left(\mathrm{S}_{7}\right)\end{array}$} \\
\hline & & Dekat & Sedang \\
\hline \multirow{6}{*}{ 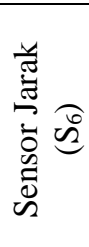 } & \multirow{2}{*}{ Dekat } & Lambat- & Sedang \\
\hline & & Kiri- & Kiri \\
\hline & \multirow{2}{*}{ Sedang } & Lambat & Sedang \\
\hline & & Kanan & Lurus \\
\hline & \multirow{2}{*}{ Jauh } & Lambat & Cepat \\
\hline & & Kanan & Kanan+ \\
\hline
\end{tabular}

Tabel 3. Aturan logika untuk mengikuti dinding kiri.

\begin{tabular}{|c|c|c|c|}
\hline & \multicolumn{2}{|c|}{$\begin{array}{c}\text { Sensor jarak } \\
\left(\mathrm{S}_{1}\right)\end{array}$} \\
\hline & & Dekat & Sedang \\
\hline \multirow{6}{*}{ 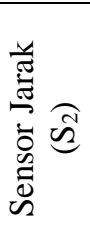 } & \multirow{2}{*}{ Dekat } & Lambat- & Sedang \\
\hline & & Kanan+ & Kanan \\
\hline & \multirow{2}{*}{ Sedang } & Lambat & Sedang \\
\hline & & Kiri & Lurus \\
\hline & \multirow{2}{*}{ Jauh } & Lambat & Cepat \\
\hline & & Kiri & Kiri- \\
\hline
\end{tabular}

\subsubsection{Behavior mengikuti jalur koridor}

Mengikuti koridor berarti robot berada diantara dinding kanan dan kiri. Pada kondisi ini robot akan bergerak pada posisi tengah jalur koridor. Dengan kata lain sensor jarak $\mathrm{S}_{2}$ dan $\mathrm{S}_{6}$ sama-sama aktif mendeteksi dinding dengan batas maksimum $40 \mathrm{~cm}$, dan juga mengontrol pergerakan robot. Pada behavior ini rancangan fungsi keanggotaan juga berdasarkan trial and error. Jika informasi jarak pada sensor $\mathrm{S}_{2}$ dekat maka sensor $\mathrm{S}_{6}$ sedang, dan sebaliknya. Ketika terdeteksi jarak oleh sensor $\mathrm{S}_{2}$ dekat dan sensor $\mathrm{S}_{6}$ sedang maka robot manuver kekanan, namun jika sensor $\mathrm{S}_{2}$ sedang dan sensor $\mathrm{S}_{6}$ dekat maka robot manuver kekiri. Oleh karena itu diputuskan variabel linguistiknya dekat dan sedang. Gambar 9 memperlihatkan fungsi keanggotaan masukan nilai jarak untuk sensor $S_{2}$ dan $\mathrm{S}_{6}$. Adapun fungsi keanggotaan keluaran untuk kecepatan dan steering ditunjukkan pada gambar 10. Berbeda dari behavior sebelumnya, pada behavior ini rentang kecepatan $5 \mathrm{~cm} / \mathrm{s}$ sampai $15 \mathrm{~cm} / \mathrm{s}$ dan steering $-10^{\circ}$ sampai $10^{\circ}$.

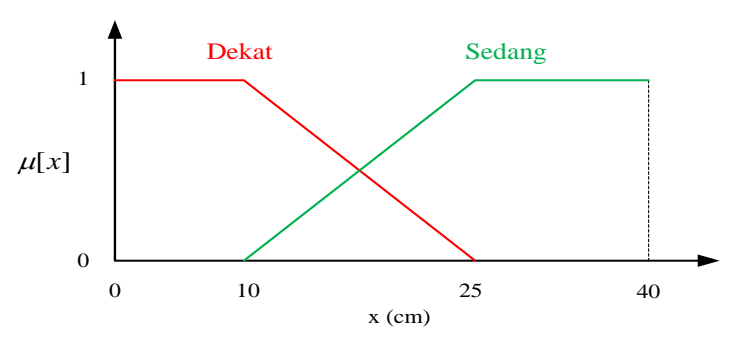

Gambar 9. Fungsi keanggotaan untuk masukan nilai jarak pada sensor $S_{2}$ dan $S_{6}$.

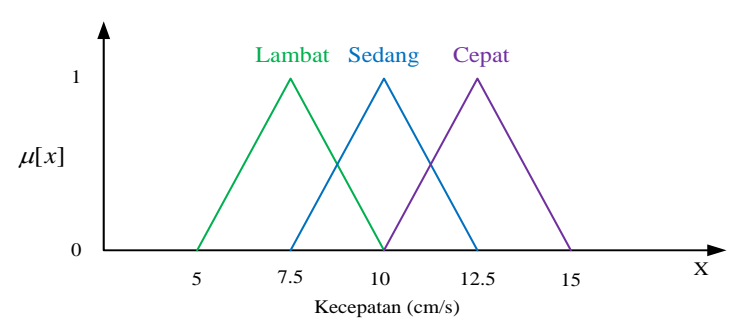

(a)

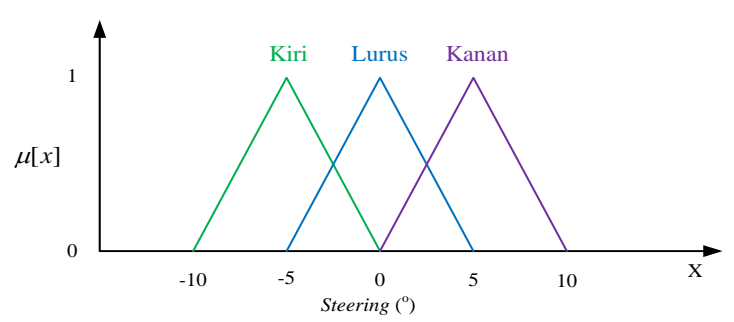

(b)

Gambar 10. Fungsi keanggotaan untuk keluaran, (a) kecepatan, dan (b) steering.

Kombinasi dari masukan jarak dengan keluaran respon robot menghasilkan aturan logika seperti yang ditunjukkan pada Tabel 4 .

Tabel 4. Aturan logika untuk mengikuti jalur koridor

\begin{tabular}{|c|c|c|c|}
\hline & \multicolumn{2}{|c|}{$\begin{array}{c}\text { Sensor jarak } \\
\left(S_{2}\right)\end{array}$} \\
\hline & & Dekat & Sedang \\
\hline \multirow{4}{*}{ 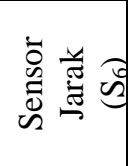 } & \multirow{2}{*}{ Dekat } & Lambat & Sedang \\
\hline & & Lurus & Kiri \\
\hline & \multirow{2}{*}{ Sedang } & Sedang & Cepat \\
\hline & & Kanan & Lurus \\
\hline
\end{tabular}

\section{HASIL DAN PEMBAHASAN}

Pengujian simulasi dilakukan dengan menempatkan robot dalam lingkungan yang ditentukan, seperti lingkungan untuk robot mengikuti dinding kanan atau kiri, koridor, menghindar halangan bahkan $u$-shape. 


\subsection{Pengujian robot pada lingkungan bebas} Pada pengujian ini robot dijalankan pada lingkungan bebas yang tidak ada halangan. Sensor pada robot tidak mendeteksi jarak atau jarak dianggap jauh, sehingga robot bergerak maju berdasarkan behavior yang diterapkan dengan kecepatan konstan $15 \mathrm{~cm} / \mathrm{s}$. Oleh karena belum ada obyek/halangan maka behavior pada robot berjalan maju bersifat prioritas rendah. Ilustrasi pergerakan robot dalam lingkungan bebas seperti ditunjukkan pada Gambar 11 . Lintasan merupakan jalur yang telah dilalui oleh robot saat ber-navigasi dalam lingkungan.

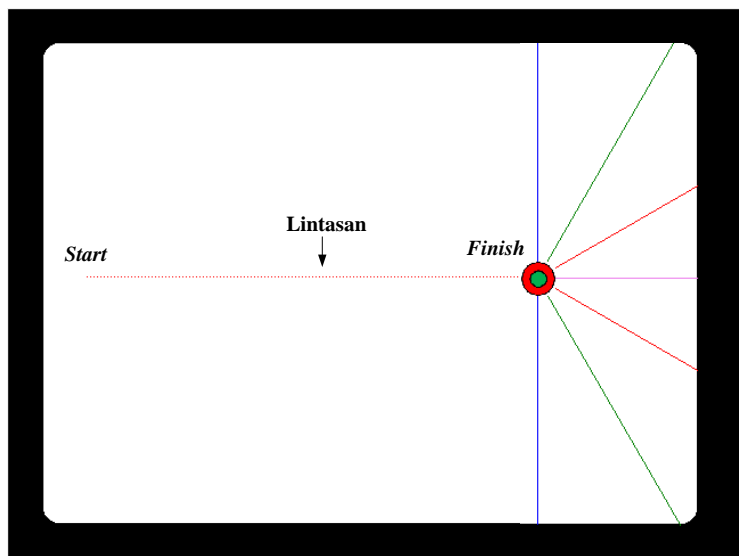

Gambar 11. Respon pergerakan robot dalam lingkungan bebas.

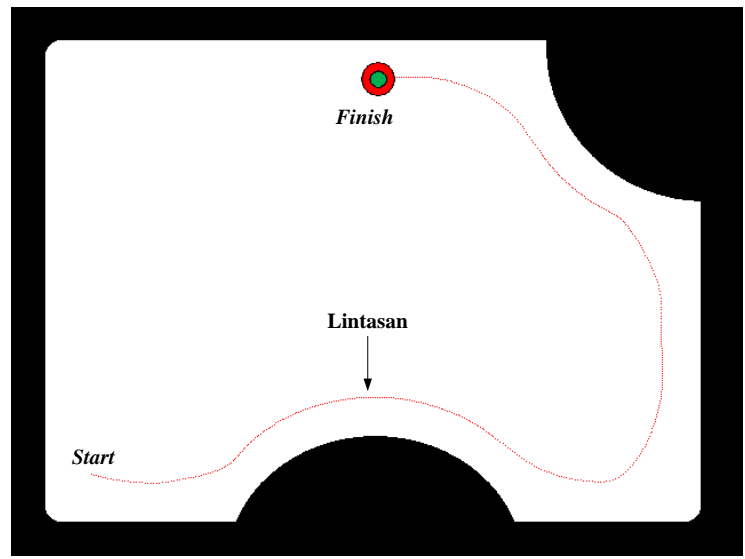

Gambar 12. Respon pergerakan robot dalam mengikuti dinding kanan.

\subsection{Pengujian robot dalam mengikuti dinding kanan \\ Pada pengujian ini bagian kanan robot ditempatkan di dekat dinding, kemudian robot dijalankan untuk melihat respon pergerakannya}

dalam mengikuti dinding kanan. Behavior ini aktif karena ada stimuli sensor bagian kanan robot mendeteksi dinding kanan. Pergerakan robot ini senantiasa mengikuti dinding dengan mempertahankan jarak terhadap dinding yaitu $\pm 18 \mathrm{~cm}$. Hal ini karena logika fuzzy bekerja dengan baik dalam mengontrol pergerakan robot (kecepatan dan steering). Gambar 12 menunjukkan respon pergerakan robot dalam mengikuti dinding kanan.

\subsection{Pengujian robot dalam mengikuti dinding kiri}

Sama seperti pada robot mengikuti dinding kanan. Robot ini juga diuji untuk mengikuti dinding kiri. Hal ini perlu supaya diketahui respon gerak robot dalam mengikuti dinding kiri. Pada behavior ini juga aktif karena ada stimuli sensor bagian kiri robot mendeteksi dinding. Logika fuzzy yang ditanam pada behavior ini juga memberikan respon gerak yang baik. Robot juga mempertahankan jarak terhadap dinding $\pm 18 \mathrm{~cm}$. Gambar 13 menunjukkan respon pergerakan robot dalam mengikuti dinding kiri.

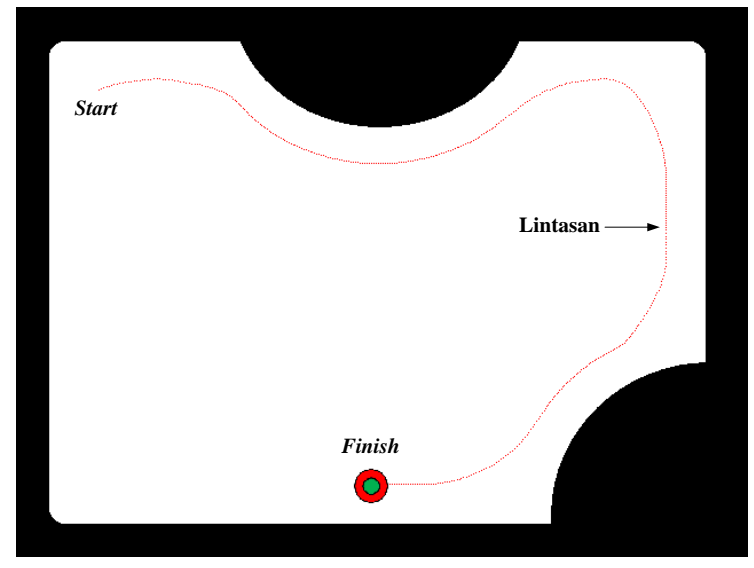

Gambar 13. Respon pergerakan robot dalam mengikuti dinding kiri.

\subsection{Pengujian robot pada jalur koridor}

Jalur koridor berarti jalur yang diapit oleh dua dinding dengan jarak cukup dekat. Dalam kondisi ini robot berprilaku untuk berjalan mengikuti jalur tersebut. Pergerakan robot dalam behavior ini juga dikontrol menggunakan logika fuzzy, sehingga robot ber-manuver dengan baik. Dalam kasus ini, jika sensor $S_{2}$ atau $S_{6}$ mendeteksi jarak lebih dari $40 \mathrm{~cm}$ maka robot berprilaku mengikuti dinding (bukan koridor). Oleh karena itu kecepatan dan steering juga 
berlaku aturan behavior mengikuti dinding. Gambar 14 memperlihatkan respon pergerakan robot dalam jalur koridor.

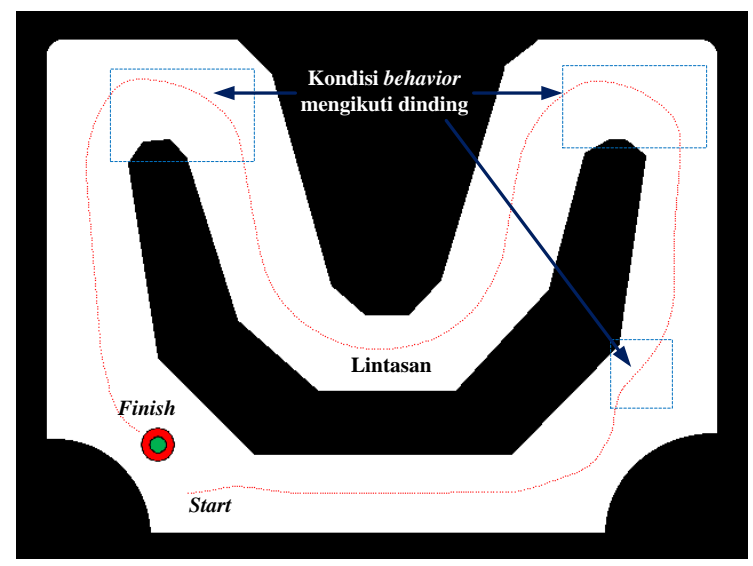

Gambar 14. Respon pergerakan robot dalam jalur koridor.

\subsection{Pengujian robot menghindar halangan}

Robot perlu diuji dalam menghindar halangan dengan tujuan untuk mengetahui respon gerakannya. Pengujian robot ini dilakukan dengan obyek berupa kotak, segitiga dan bulat. Obyek tersebut secara bergantian ditempatkan di depan robot. Robot dalam menghindari obyek kotak mulai merespon saat sensor depan mendeteksi jarak $50 \mathrm{~cm}$ seperti yang ditunjukkan pada Gambar 15(a). Kasus serupa juga dilakukan pada obyek segitiga, tampak robot juga menghindar halangan seperti terlihat pada Gambar 15(b). Namun berbeda untuk kondisi obyek bentuk bulat, robot juga mendeteksi obyek lalu behavior menghindar. Saat robot menghindar (aksi belok kiri) maka sensor bagian kanan $\left(\mathrm{S}_{6}\right.$ dan $\left.\mathrm{S}_{7}\right)$ mendeteksi objek, sehingga behavior robot berubah menjadi right-wall following. Hal ini juga berlaku jika robot saat belok kanan kemudian sensor kirinya aktif (left-wall following). Adapun pergerakan robot dalam menghindar obyek bulat ditunjukkan pada Gambar 15(c).

\subsection{Pengujian robot pada lingkungan $u$-shape}

Adanya behavior pada kondisi u-shape untuk mengatasi keterbatasan behavior menghindar halangan. Pengujian ini juga bertujuan untuk mengetahui respon gerak robot saat dalam kondisi jarak sensor depan $\left(\mathrm{S}_{4}\right)$ terlalu dekat (kurang dari $20 \mathrm{~cm}$ ) dengan obyek/dinding (u-shape). Behavior ini tidak menggunakan logika fuzzy namun logikanya berdasarkan perbandingan dari jarak yang dideteksi oleh sensor $S_{1}$ dan $S_{7}$. Pada kondisi ini diberikan kecepatan konstan $5 \mathrm{~cm} / \mathrm{s}$ dan steering konstan $10^{\circ}$ (ke kiri atau kanan). Gambar 16 menunjukkan respon pergerakan robot dalam kondisi $u$-shape. Berdasarkan Gambar 16 bahwa robot ber-manuver kearah yang dianggap masih luas. Oleh karena itu, robot selalu ber-navigasi pada lingkungan $u$-shape.

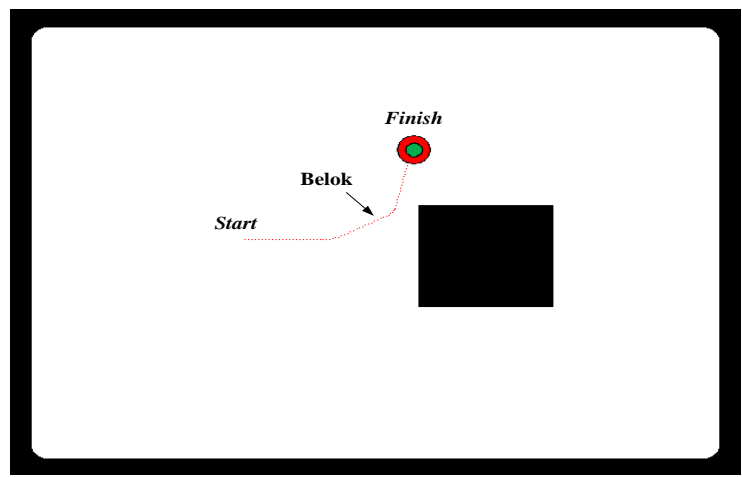

(a)

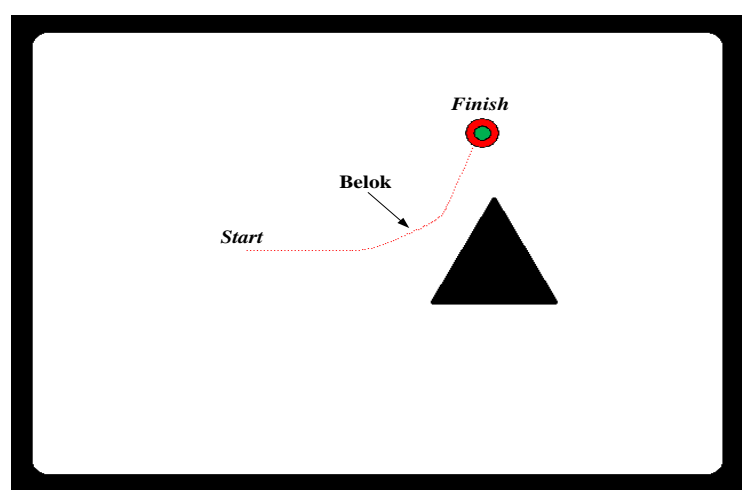

(b)

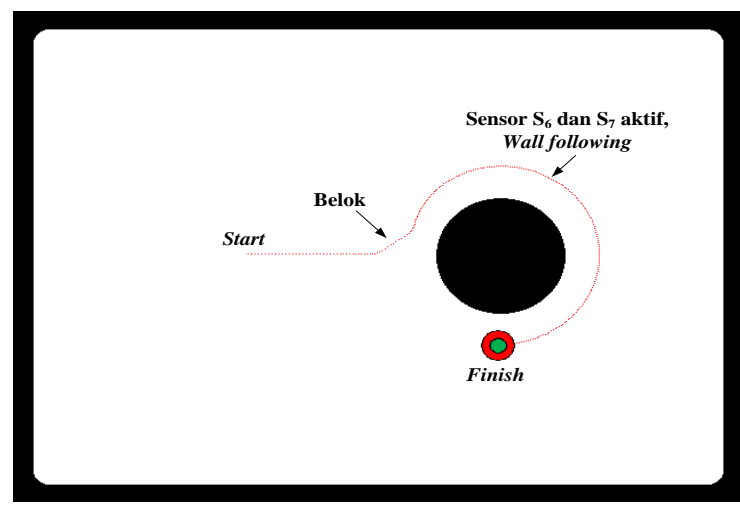

(c)

Gambar 15. Respon pergerakan robot dalam menghindar halangan, (a) objek kotak, (b) segitiga, dan (c) bulat. 


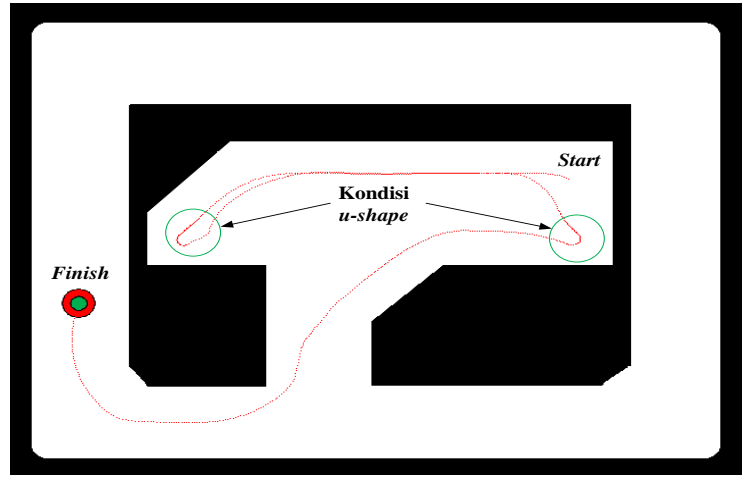

Gambar 16. Respon pergerakan robot pada kondisi $u$-shape.

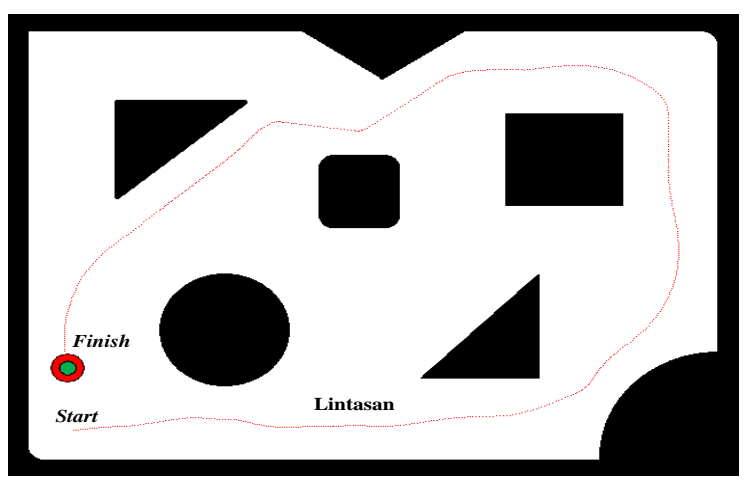

(a)

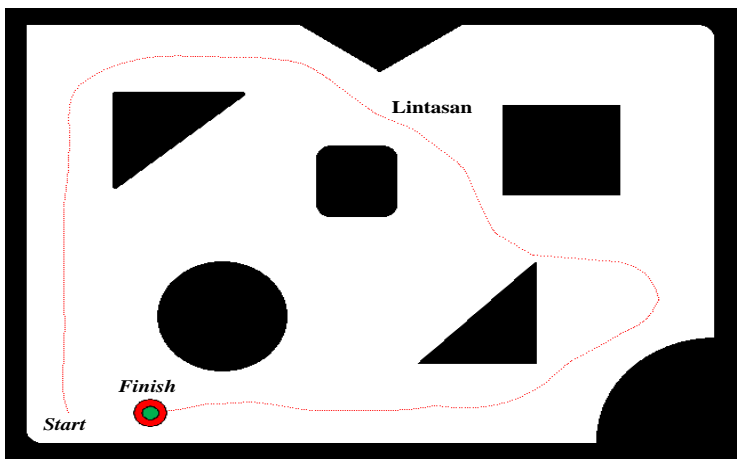

(b)

Gambar 17. Respon gerak robot dalam lingkungan komplek.

(a) lintasan robot mengikuti dinding kanan,

(b) mengikuti dinding kiri.

\subsection{Pengujian robot dalam lingkungan komplek.}

Pada lingkungan komplek simulasi robot ditempatkan dekat dinding (kanan atau kiri). Ini bertujuan agar robot berprilaku mengikuti dinding, namun saat ada halangan maka robot ber-manuver sesuai behavior yang diterapkan. Gambar 17 menunjukkan pergerakan robot (manuver) dalam lingkungan komplek. Hal ini menunjukkan bahwa integrasi logika fuzzy dan behavior yang diimplementasikan dalam robot dapat bekerja dengan baik pada lingkungan dengan berbagai kondisi.

\section{KESIMPULAN}

Simulasi mobile robot berukuran diameter 15 $\mathrm{cm}$, dan dilengkapi sensor jarak sebanyak tujuh sensor yang diaplikasikan dalam program visual. Sensor-sensor tersebut dibagi menjadi kelompok untuk membentuk beberapa behavior dalam manuver robot. Robot telah dilakukan pengujian dalam lingkungan dengan berbagai kondisi. Integrasi logika fuzzy dan behavior yang diimplementasikan pada robot memberikan hasil yang baik. Pengembangan pada penelitian selanjutnya akan dirancang sistem robot untuk keperluan aplikasi.

\section{UCAPAN TERIMA KASIH}

Terima kasih disampaikan kepada jurusan Sistem Komputer dan Fakultas Ilmu Komputer Universitas Sriwijaya.

\section{DAFTAR PUSTAKA}

[1] Nurmaini, S. dan Tutuko, B., A New Classification Technique in Mobile Robot Navigation, Telkomnika, Vol. 9, No. 3, hal 453-464, (2011).

[2] Sembiring, S., Baafai, U., dan Tarigan, P., Implementasi Arsitektur Behavior-Based dengan Menggunakan Fuzzy untuk Navigasi Car-Like Mobile Robot dalam Lingkungan yang Tak Dikenal, Jurnal Generic, Vol. 9, No. 2, hal 320-331, (2014).

[3] Hamzah, M.I. dan Abdall, T.Y., Mobile Robot Navigation using Fuzzy Logic and Wavelet Network, International Journal of Robotics and Automation (IJRA), Vol. 3, No. 3, hal 191-200, (2014).

[4] Ardisasmita, M.S., Pengembangan Robot Mobil Otonom Menggunakan Sistem Kendali Fuzzy dan Jaringan Syaraf Tiruan, Risalah Lokakarya Komputasi dalam Sains dan Teknologi Nuklir XIV, hal 157-170, (2003).

[5] Wang, H., Chen, C., dan Huang, Z., Ultrasonic Sensor Based Fuzzy-Neural 
Control Algorithm of Obstacle Avoidance for Mobile Robot, Springer-Verlag Berlin Heidelberg, Part 1, hal 824-833, (2007).

[6] Aribowo, F.W., Fatchur, A., Setiawan, I., Robot Mobile Penjejak Arah Cahaya Dengan Kendali Logika Fuzzy, Transmisi, Jurnal Teknik Elektro, Jilid 10, No. 3, hal 144-150, (2008).

[7] Adriansyah, A., Gunardi, Y., Badaruddin, dan Ihsanto, E., Goal-Seeking BehaviorBased Mobile Robot Using Particle Swarm Fuzzy Controller, Telkomnika, Vol. 13, No. 2, hal 528-538, (2015).

[8] Pitowarno E., Robotika: Desain, Kontrol, dan Kecerdasan Buatan, Andi Offset, (2006).

[9] Ping, J., Xiao-fang, H., dan Ai-dong, G., Mobile Robot gas Source Localization Based on Behavior Strategies, Proceeding of the $33^{\text {rd }}$ Chinese Control Conference, hal 8304-8308, (2014).

[10] Sugiarto, I., Untung, L.L., dan Rahman, M.I., Implementation of Fuzzy Logic in FPGA for Maze Tracking of a Mobile Robot Based on Ultrasonic Distance Measurement, Jurnal Teknik Elektro, Vol. 8, No.2, hal 96-102, (2008).

[11] Fahmizal dan Kuo, C., Development of a Fuzzy Logic Wall Following Controller for Steering Mobile Robots, Proceedings of International Conference on Fuzzy Theory and Its Application, hal 7-12, (2013).

[12] Farooq, U., Khalid, A., Amar, M., Habiba, A., Shafique, S., dan Noor, R., Design and Low Cost Implementation of a Fuzzy Logic Controller for Wall Following Behavior of a Mobile Robot, International Conference on Signal Processing Systems, vol. 2, hal 740-746, (2010).

[13] Rendyansyah, Rivai, M., dan Purwanto, D., Implementasi kendali Logika Fuzzy Untuk Mengontrol Pergerakan Olfactory Mobile Robot Dalam Mengikuti Dinding Obyek, Prosiding Seminar Nasional Matematika dan Pendidikan Matematika, hal 384-395, (2015).

[14] Darwison dan Wahyudi, R., Kontrol Kecepatan Robot Hexapod Pemadam Api Menggunakan Metoda Logika Fuzzy, Jurnal Nasional Teknik Elektro, Vol. 4, No. 2, hal 227-234, (2015).

\section{Biodata Penulis}

Rendyansyah, lahir di Inderalaya, Sumatera Selatan, Indonesia. Pendidikan SD, SMP dan SMA di Kabupaten Ogan Ilir, Indonesia. Pada tahun 2007 melanjutkan kuliah di jurusan Sistem Komputer Universitas Sriwijaya dan memperoleh gelar sarjana komputer pada tahun 2011. Pernah bekerja sebagai tenaga laboratorium kendali dan robotika pada fakultas ilmu komputer UNSRI tahun 2011 sampai 2013. Tahun 2013 melanjutkan pendidikan magister teknik elektronika ITS Surabaya, dan selesai pada tahun 2015. Kemudian diterima sebagai tenaga pengajar S1 sistem komputer UNSRI.

Kemahyanto Exaudi, lahir di Lampur, Bangka Belitung, Indonesia. Pendidikan SD, SMP dan SMA di Bangka Belitung, Indonesia. Pada tahun 2008 melanjutkan kuliah di jurusan Sistem Komputer Universitas Sriwijaya dan memperoleh gelar sarjana komputer pada tahun 2011. Pernah bekerja sebagai tenaga laboratorium kendali dan robotika pada fakultas ilmu komputer UNSRI tahun 2011 sampai 2013. Tahun 2013 melanjutkan pendidikan magister teknik elektronika ITS Surabaya, dan selesai pada tahun 2015. Kemudian diterima sebagai tenaga pengajar S1 sistem komputer UNSRI. 